\title{
EHMTI-0351. PFO closure with migraine in East Tallinn Central Hospital (Estonia)
}

\author{
T Toomsoo $^{1 *}$, A Kaasik², S Margus ${ }^{2}$ \\ From 4th European Headache and Migraine Trust International Congress: EHMTIC 2014 \\ Copenhagen, Denmark. 18-21 September 2014
}

\section{Introduction}

PFO closure may reduce the frequency and severity of migraine headaches in patients with significant right-toleft shunts.

\section{Methods}

Between January 2008 and March 2013 consecutive patients (mean age, 34,8 years; $83.4 \%$ women) with migraine symptoms were given a prior PFO closure with the Cardia PFO occluder for migraine attack prevention. All patients had right-to-left shunts; the shunts were associated with migraine symptoms in 8 patients and all eight had aura symptoms. Septal aneurysm was present in 4 (i.e. 50\%) migraine patients. All patients had very frequent migraine attacks, more then 7 times per month. All 8 patients underwent transoesophagael echocardiography after PFO closer with a clinical follow-up after $24 \mathrm{hr}$, then after 6 , and 12 months, and then yearly.

\section{Results}

An acute migraine attack occurred after PFO closure in $2(25 \%)$ of 8 patients. There was a significant reduction $(\backslash 50 \%)$ in the number and intensity of attacks in 6 (75\%) of the 8 patients after the 3-month follow- up period but in $1(12.5 \%)$ similar attacks occurred before closure. After the 12-month follow-up period, migraine had ceased in $5(62.5 \%)$ patients, and $3(37,5 \%)$ had a reduction in the migraine recurrence rate and disabling symptoms. These results were maintained in the followup (about 72 months). Only one patient remained migraine attacks, but not more than one attack per month about three month follow up period after PFO closure. There was an overall improvement in $82.5 \%$ of the treated patients.

${ }^{1}$ Neurology, East Tallinn Central Hospital, Tallinn, Estonia

Full list of author information is available at the end of the article

\section{Conclusions}

Percutaneous PFO closure in migraineurs may provide beneficial mid-term and long-term results, with significant reduction in the intensity and frequency of headache symptoms.

No conflict of interest.

\section{Authors' details}

${ }^{1}$ Neurology, East Tallinn Central Hospital, Tallinn, Estonia. ${ }^{2}$ Angiography, East Tallinn Central Hospital, Tallinn, Estonia.

Published: 18 September 2014

doi:10.1186/1129-2377-15-S1-M12

Cite this article as: Toomsoo et al:: EHMTI-0351. PFO closure with migraine in East Tallinn Central Hospital (Estonia ). The Journal of Headache and Pain 2014 15(Suppl 1):M12.

\section{SpringerOpen ${ }^{\odot}$}

(c) 2014 Toomsoo et al; licensee Springer. This is an Open Access article distributed under the terms of the Creative Commons Attribution License (http://creativecommons.org/licenses/by/2.0), which permits unrestricted use, distribution, and reproduction in any medium, provided the original work is properly cited.
Submit your manuscript to a SpringerOpen ${ }^{\circ}$ journal and benefit from:

- Convenient online submission

- Rigorous peer review

- Immediate publication on acceptance

- Open access: articles freely available online

- High visibility within the field

Retaining the copyright to your article

Submit your next manuscript at $>$ springeropen.com 